\title{
External Ear Pain, CTCAE 5.0
}

National Cancer Institute

\section{Source}

National Cancer Institute. External Ear Pain, CT CAE 5.0. NCI Thesaurus. Code C146745.

A disorder characterized by a sensation of marked discomfort in the external ear region. 